\section{Diagnostic, Clinical and Epidemiological aspects of dairy cows naturally infected by Trypanosoma vivax in the states of Pernambuco and Alagoas, Brazil}

\author{
Diagnóstico, aspectos clínicos e epidemiológicos de bovinos \\ leiteiros naturalmente infectados por Trypanosoma vivax nos \\ estados de Pernambuco e Alagoas, Brasil
}

\author{
Adony Querubino de Andrade Neto**, Carla Lopes de Mendonça², Rodolfo José Cavalcanti Souto², \\ Paulo Henrique Sampaio ${ }^{3}$, Otávio Luiz Fidelis Junior ${ }^{3}$, Marcos Rogério André4, Rosangela Zacarias Machado ${ }^{4}$ \& \\ Jose Augusto Bastos Afonso ${ }^{2}$ \\ 'TVeterinary, MSc, PhD. Programa de Pós-graduação em Medicina Veterinária, Universidade Federal Rural de Pernambuco - \\ UFRPE, Recife, PE, Brasil \\ 2Veterinary, Dr. Clínica de Bovinos, Universidade Federal Rural de Pernambuco -UFRPE, Garanhuns, PE, Brasil \\ ${ }^{3}$ Veterinary, PhD. Departamento de Medicina Veterinária, Universidade Estadual Paulista - UNESP, Jaboticabal, SP, Brasil \\ ${ }^{4}$ Veterinary, Dr. Departamento de Patologia Veterinária, Universidade Estadual Paulista - UNESP, Jaboticabal, SP, Brasil
}

\begin{abstract}
Trypanosoma vivax is the most pathogenic hemoparasite of ruminants, causing huge economic losses to the producer when prevalent in the herd. This study aims to characterize the trypanosomiasis in naturally infected cattle in order to assess the clinical findings, epidemiological risk factors, and diagnosis of this disease in outbreaks occurring in the states of Pernambuco and Alagoas, northeastern Brazil. For this purpose, historical and clinical examinations, blood collection and clinical monitoring were performed in 109 animals presenting illness for a period of one year. The main clinical findings were fever, apathy, anorexia, diarrhea, progressive weight loss, lymphadenopathy, pale mucous, incoordination, aggressiveness, abortion, decrease in milk production, and high mortality. Out of 109animals, 94\% (103/109) were seropositive to Trypanosoma vivax by ELISA, 92\% (100/109) were seropositive for IFAT, 15\% (17/109) were positive in conventional PCR assay based on the cathepsine L gene, and 9\% (10/109) showed the presence of Trypanosoma vivax trypomastigotes in stained-blood smears. In 13 samples, blood counts revealed that 69.23\% (9/13) showed normocytic normochromic anemia and 53.84\% (7/13) had leukocytosis, in 46.15\% (6/13) neutrophilia and regenerative left shift. In 72 samples, the hematocrit, plasma protein, and fibrinogen were also examines. The hematocrit presented an average of $22 \%$ (10\% to $37 \%$ ), plasma protein a mean value of $7.55 \mathrm{~g} / \mathrm{dl}(5.4 \mathrm{~g} / \mathrm{dl}$ to $10.0 \mathrm{~g} / \mathrm{dl})$, and plasma fibrinogen a mean value of 700mg/dl (200mg/dl to $1600 \mathrm{mg} / \mathrm{dl}$ ). The sequencing of DNA samples revealed 100\% identicalness to Trypanosoma vivax by BLAST analysis. The main factors involved in the spread of the disease were: the ingress of animals without prior tests and quarantine into the properties, application of oxytocin with shared needles contaminated by blood at the time of lactation, and the restriction of the disease in the lactation herd. The transmission of Trypanosoma vivax occurred through the sharing of needles among lactating animals during application of oxytocin after the entry of carrier animals in the herd. Serological tests demonstrated a high rate of seropositive animals, however, conventional PCR and blood smears revealed a low positive rate because the animals were already being treated with trypanocid drugs. It is concluded that trypanosomiasis is a disease to be considered in the cattle regions studied as the cause of outbreaks. Hygiene and security actions should be taken during the administration of oxytocin in lactating cows. In fact, this practice, when performed using shared needles and without disinfection, is the main risk factor in the transmission of trypanosomiasis in dairy herds among regions where the disease is prevalent, increasing the challenge of reinfection of animals.
\end{abstract}

Keywords: diagnosis, ruminant, Trypanosoma vivax.

\section{Resumo}

O Trypanosoma vivax é o hemoparasito mais patogênico para ruminantes, causando grandes perdas econômicas para o produtor quando prevalente no rebanho. Este trabalho se propõe a caracterizar a tripanossomose em bovinos por achados clínicos, fatores epidemiológicos de risco e diagnóstico dessa
How to cite: Andrade Neto, A.Q., Mendonça, C.L. Souto, R.J.C., Sampaio, P.H., Fidelis Junior, O.L., André, M.R., Machado, R.Z. \& Afonso, J.A.B. (2019). Diagnostic, Clinical and Epidemiological aspects of dairy cows naturally infected by Trypanosoma vivax in the states of Pernambuco and Alagoas, Brazil. Brazilian Journal of Veterinary Medicine, 47 e094319. https://doi.org//10.29374/2527-2179. bjvm094319

Conflict of interests: No conflict of interests declared concerning the publication of this article.

Received: May 19, 2018.

Accepted: December 13, 2018.

The study was carried out at Clínica de Bovinos, Universidade Federal Rural de Pernambuco UFRPE, Garanhuns, PE, Brasil and Departamento de Patologia Veterinária, Universidade Estadual Paulista - UNESP, Jaboticabal, SP, Brasil.

\section{*Correspondence}

Adony Querubino de Andrade Neto Programa de Pós-graduação em Ciência Veterinária, Universidade Federal Rural de Pernambuco - UFRPE, Clínica de Bovinos Av. Bom Pastor, s/n, Bairro Boa vista CEP 55292-272 - CP 152 - Garanhuns (PE), Brasil

E-mail: adony_neto@hotmail.com the terms of the Creative Commons Attribution Non-Commercial License which permits unrestricted non-commercial use, distribution, and reproduction in any medium provided the original work is properly cited. 
doença em surtos ocorridos no agreste pernambucano e alagoano do Brasil. Nas propriedades foram realizados levantamentos dos históricos e exames clínicos, coletas de sangue e acompanhamento clínico de 109 animais doentes por um período de um ano. Os achados clínicos foram: febre, apatia, anorexia, diarreia, emagrecimento progressivo, linfoadenomegalia, mucosas pálidas, incoordenação motora, agressividade, aborto, queda na produção de leite e alta mortalidade. Das 109 amostras utilizadas, 94\% (103/109) foram soropositivas no ELISA, 92\% (100/109) foram soropositivas para IFAT, 15\% (17/109) positivas para PCR convencional e 9\% (10/109) foram evidenciadas presença do Trypanosoma vivax no esfregaço sanguíneo. Em 13 amostras, foram realizados hemogramas o que revelou que 69,23\% (9/13) apresentaram anemia normocítica normocrômica e 53,84\% (7/13) apresentaram leucocitose, em 46,15\% (6/13) neutrofilia e desvio a esquerda regenerativo. Em 72 amostras analisou-se também o hematócrito, proteína plasmática e o fibrinogênio. O hematócrito teve valor médio de $22 \%$ (10\% a 37\%), a proteína plasmática teve valor médio de $7,55 \mathrm{~g} / \mathrm{dl}$ (5,4g/dl a 10,0g/dl) e o fibrinogênio plasmático teve valor médio de $700 \mathrm{mg} / \mathrm{dl}$ (200mg/dl a 1600mg/dl). O sequenciamento das amostras de DNA revelou 100\% de similaridade com Trypanosoma vivax. Os principais fatores envolvidos na propagação da doença foram:a entrada de animais portadores do Trypanosoma vivaxnas propriedades sem exames prévios e quarentena, a aplicação de ocitocina com compartilhamento de agulhas contaminadas por sangue no momento da ordenha e a restrição da doença ao rebanho em lactação. Os testes sorológicos apresentaram uma melhor taxa de detecção de animais soropositivos, entretanto, o PCR e o esfregaço sanguíneo revelaram uma baixa taxa de detecção em virtude de os animais já estarem sendo medicados continuamente com drogas tripanocidas. Conclui-se que a tripanossomose é uma doença a ser considerada na bovinocultura das regiões estudadas como causadora dos surtos. Medidas higiênicas e de seguridade devem ser adotadas durante a administração de ocitocina nas vacas em lactação, sendo esta prática, quando realizada com uso de agulhas compartilhadas e sem desinfecção, o principal fator de risco na transmissão da tripanossomose em rebanhos leiteiros em regiões onde a doença é prevalente, aumentando o desafio de reinfecções entre os animais.

Palavra-chave: diagnóstico, ruminante, Trypanosoma vivax.

\section{Introduction}

Trypanosomes are diseases caused by protozoa of the genus Trypanosoma spp., of which Trypanosoma (Duttonnela) vivax is considered the most pathogenic and important hemoparasite for ruminants, being widespread in the African continent and in Central and South America (Ventura et al., 2001).

In the Americas, the main route of transmission is through the mechanic vectors tabanidae, Stomoxys calcitrans and Haematobia irritans, and through the iatrogenic route (Oliveira et al., 2009; Cadioli et al., 2012). Natural infection by this hemoparasite is already well known and reported in several countries, such as; Venezuela, Paraguay, Colombia, Suriname, Guyana, Bolivia, Peru, and Costa Rica (Quispe et al. 2003; Suárez et al., 2009).

In Brazil, the first outbreaks of the disease occurred in the state of Pará in ruminants (Boulhosa, 1946; Shaw \& Lainson, 1972) and since then several others have been reported in the country, such as in Mato Grosso (Silva et al., 1996), Amapá and Rio de Janeiro (Madruga et al., 2006), Tocantins (Linhares et al., 2006), Paraíba (Batista et al., 2007), Santa Catarina (Silva et al., 2007), Maranhão (Guerra et al., 2008), Minas Gerais (Carvalho et al., 2008), Rio Grande do Sul (Silva et al., 2009), São Paulo (Cadioli et al., 2012), Goiás (Bastos et al., 2017), and Sergipe (Vieira et al., 2017).

In the state of Pernambuco, the first register was recorded in Zona da Mata in a herd of dairy cattle (Pimentel et al., 2012). The first serological test for antibodies to Trypanosoma vivax confirmed the parasite circulation in all mesoregions studied (Litoral, Zona da Mata, Agreste, and Sertão) with frequencies varying from $11.90 \%$ to $15.99 \%$, thus characterizing the state as an area of enzootic instability (Guerra et al., 2013).

The epidemiological factors associated with trypanosomosis in several areas of Brazil show that the occurrence of this parasite takes place in a differentiated manner. In this sense, in the Pantanal region of Mato Grosso, for example, cattle herds are suffering serious negative impacts of an economic nature, especially in areas where there is enzootic instability for the disease (Madruga et al., 2006; Batista et al., 2012; Cadioli et al., 2012; Guerra et al., 2013).

The mortality rate in animals infected by the parasite is generally high, reaching 80\% (Cortez et al., 2006). The main clinical signs include decreased milk production, apathy, anorexia, progressive 
weight loss, lymphadenopathy, mucosal pallor, diarrhea, weakness and fever, as well as serious reproductive damage such as abortion, dystocia, and infertility. Nervous alterations are also observed, such as aggressiveness, incoordination, and ataxia (Linhares et al., 2006; Batista et al., 2007; Cuglovici et al., 2010; Batista et al., 2012).

In this context, the present study aimed to investigate the epidemiological characteristics, as well as the clinical and laboratory status of trypanosomiasis in bovines from dairy farms in the states of Pernambuco and Alagoas, as well as reporting the first occurrence of trypanosomiasis in cattle in the state of Alagoas, Brazil.

\section{Material and methods}

\section{Characterization of outbrealks and clinical signs}

The outbreaks described here occurred in three dairy farms located in the northeastern region of Brazil, two in the state of Pernambuco and the other in the state of Alagoas. The first outbreak occurred at the beginning of November 2013 on a farm in the municipality of BomConselho (latitude 09010 ' 11 "S and longitude $36040^{\prime}$ ' 47" W), altitude 654m, average temperature $21.6^{\circ} \mathrm{C}$. The average annual rainfall is $995 \mathrm{~mm}$ in the state of Pernambuco with a semi-arid climate (Mascarenhas et al., 2005). The dairy herd was composed of 120 crossbred (Girolando) animals, of which 60 animals were lactating and being mechanically milked. The breeding system was semi-intensive and produced an average of $1100 \mathrm{~L} / \mathrm{milk} /$ day, before the disease, which reduced to 250 liters when the animals began to fall ill. The animals were fed corn silage, corn meal, and soybean meal. On the first visit to the farm, information provided by the owner regarding the symptomatology presented by the animals was apathy, anorexia, weakness, progressive thinning, pale mucosa, enlarged lymph nodes, diarrhea, fever, and abortion, and one animal presented aggression and incoordination, and evolved to death. In total, 30 animals died after presenting this symptomatology, and the disease affected only lactating cows. Five diseased animals were hospitalized at the Clinic of Garanhuns, campus/UFRPE.

The second outbreak occurred at the end of January 2014, at a farm in the municipality of Pedra, southern agreste (latitude $08^{\circ} 29^{\prime} 49^{\prime \prime}$ and longitude 36 56' 27"), altitude 617 meters, average temperature $25^{\circ} \mathrm{C}$, with an average annual rainfall of $624.88 \mathrm{~mm}$ (Mascarenhas et al., 2005). The farm has a total area of 100 hectares, composed of 100 crossbred (Girolando) animals; of these, 62 animals were lactating and mechanically milked. The production system was semi-intensive, producing 600 liters/milk/day before the disease and 230 liters after the animals began to fall ill. The animals were fed corn silage, corn meal, Manihot esculenta, and native pasture. Two diseased animals were admitted to the CBG, with a history of apathy, progressive weight loss, diarrhea, pale mucous membranes, weakness, anorexia, incoordination and drop in milk production. Some animals presented aggression and ataxia, and eight animals died. Only lactating animals became ill.

The third outbreak occurred at the end of September 2014, on a farm in the city of Arapiraca, in the central region of Alagoas state, wild agreste ( $9^{\circ} 45^{\prime} 09^{\prime \prime}$ latitude and $36^{\circ} 39^{\prime} 40^{\prime \prime}$ longitude), altitude $264 \mathrm{~m}$, characterized by high temperatures, with an average annual temperature of $25^{\circ} \mathrm{C}$, and annual total precipitation in the range of 750 to $1000 \mathrm{~mm}$ (Mascarenhas et al., 2005). The farm has a total area of 200 hectares, an effective herd of 250 crossbred (Girolando) animals, of which 102 were lactating and mechanically milked. The average production was 900L/milk/day which dropped to 420 liters after the animals became ill. The breeding system was semi-intensive. During the first visit, the veterinarian assisting the farm, as well as the caretakers, reported that four months previously, animal deaths had occurred on the farm. These animals presented decreased milk production, apathy, anorexia, weight loss, fever, sialorrhea, pale mucous membranes. In addition, one animal presented nervous symptoms, two animals abortion and, in total, 15 animals died. The disease only affected lactating cows.

In all the properties visited, an epidemiological questionnaire was applied to the veterinarian, owner, or other caregivers responsible for the property, in order to obtain information about the sanitary measures adopted during the outbreak, which medicines were being used and respective doses, health conditions of the herd, as well as whether there had been any recent introduction of animals to the farm or movement of animals at fairs or exhibitions. The facilities and management 
practices were inspected to obtain information that could contribute to characterization of the outbreak and factors that directly favored its development. All diseased animals were examined according to Dirksen et al. (1993) and followed up at four-monthly intervals with observation of the evolution of clinical alterations in a prospective study.

\section{Blood collection, parasite detection, and haematological analysis}

A total of 125 blood samples were collected from all three properties, including only diseased or lactating animals. These were collected through venipuncture of the external jugular vein, using Vacutainer ${ }^{\circledR}$ tubes with anticoagulant EDTA, and without anticoagulant, to obtain serum. Whole blood and serum samples were quickly chilled in polystyrene with ice and taken to the clinical laboratory of the Bovine Clinic. Samples with anticoagulant were used for parasitological and hematological analyzes. A total of 109 samples obtained without anticoagulant were centrifuged for 10 minutes at $1500 \mathrm{rpm}$. The serum samples obtained were placed in $1.5 \mathrm{~mL}$ microtubes stored in a freezer at $-80^{\circ} \mathrm{C}$ and used for serological tests. In addition, 40 of the whole blood samples were preserved in ethanol and 69 in anticoagulant EDTA, and frozen at $-80{ }^{\circ} \mathrm{C}$, later used for DNA extraction in molecular testing. Serological and molecular tests were performed in the immune parasitology sector of the FCAV-UNESP, Jaboticabal, São Paulo. Of the 125 samples collected, hemogram of the clinically diseased animals was performed in 13 samples and in 72 samples only the hematocrit, plasma protein, and fibrinogen, in addition to parasitological examination. Haematological analysis was performed as described by Jain (1993). Blood smears obtained from the 109 whole blood samples were stained with quick panoptic and the search for Trypanosoma vivax was carried out by direct observation in light microscopy according to Silva et al. (2002).

\section{Serological diagnosis}

\section{Indirect Immunofluorescence Reaction (IFAT)}

The IFAT slides were prepared and sensitized using blood samples from goats experimentally inoculated with Trypanosoma vivax, "Lins" strain (Cadioli et al., 2012), obtaining the antigen according to González et al. (2005). Serum samples were diluted 1:80 in 1\% PBS buffered saline, pH $7.2\left(1.3 \mathrm{M} \mathrm{NaCl}, 27 \mathrm{mMKCl}, 56 \mathrm{mM} \mathrm{Na}_{2} \mathrm{HPO}_{4^{\prime}} 10 \mathrm{mM} \mathrm{KH}_{2} \mathrm{PO}_{4^{\prime}} 9.2 \mathrm{mM} \mathrm{NaH}_{2} \mathrm{PO}_{4}\right)$ following the methodology recommended by Aquino et al. (1999).

\section{Immunoenzymatic Assay (ELISA)}

Antigenic purification was performed according to González et al. (2005). Subsequently, the obtained antigen was sonicated (750wUltrasonicProcessor, Coleparmer - Canada).The protein content of the soluble antigen was determined using the bicinchoninic acid method with BCA Reagents Kits (Pierce Chemical Company), according to the manufacturer, and calculated by linear regression. The ELISA test was performed following the recommendations of Aquino et al. (1999).

\section{Molecular diagnosis}

\section{Polymerase Chain Reaction (PCR)}

DNA extraction from the 69 samples with EDTA anticoagulant at 10\% which were frozen was performed using a QIAampDNAeasy kit (Qiagen ${ }^{\circledR}$, USA) according to the manufacturer's recommendations. The 40 whole blood samples collected in ethanol were subjected to DNA extraction using a lysis buffer and chloroform isoamy (25:24:1), according to Rodrigues et al. (2010). The DNA extracted from the samples was quantified by spectrophotometry (Nanodrop ${ }^{\circledR 2000 ;}$ ThermoScientific). DNA amplification targeted the cysteine protease-coding sequence (cathepsin L, CatL-Like) (Cortez et al., 2009). The products were separated on a $2 \%$ agarose gel containing ethidium bromide (Invitrogen ${ }^{\circledR}$ ) and the gel developed in a ChemiDoc ${ }^{\mathrm{TM}}$ MP imaging system (BioRad, USA). 


\section{DNA sequencing and sequence analysis}

Two positive samples were purified using the Silica Gel Extraction Kit (Fermentas, São Paulo, SP). These purified samples were sequenced using an automated sequencer (ABI Prism 310 Genetic Analyzer - Applied Byosystem/Perkin Elmer) in both directions.The quality of the electropherograms was initially analyzed in the program FinchTV 1.4.0. and to correctly determine the nucleotide composition, the electropherograms were also submitted to the PhredPhrap program. Only sequences with expected sizes and without artefacts on the electropherograms were submitted to BLASTn for identification.

\section{Data analysis}

The statistical analysis of the data was performed in a descriptive way, determining the frequency distributions using the mean and standard deviation of the relative variables analyzed.

\section{Results}

\section{Characterization of the outbreaks and clinical findings}

\section{Property of the first outbreak}

The animals hospitalized in the CBG presented body condition grade II, anorexia, weakness, diarrhea, and enlarged lymph nodes. One animal died before the clinical examination. The investigation of hemoparasites by blood smear did not reveal the presence of trypomastigote forms of Trypanosoma spp.. Two animals died a few days after hospitalization. In the anatomopathological examination performed on the three animals that died, an unspecific liver disease was highlighted, and one also presented thrombosis of the mammary vein and abscedative thromboembolic pneumonia. On the first visit to the farm, it was found that the disease was affecting only lactating cows. These were examined and the most common clinical findings were apathy, anorexia, pale mucous membranes, fever, weight loss, grade II body score, lymphadenomegaly, and diarrhea (Figure 1A). In the first outbreak of the disease, 24 animals died (Figure 1B) of these, five animals

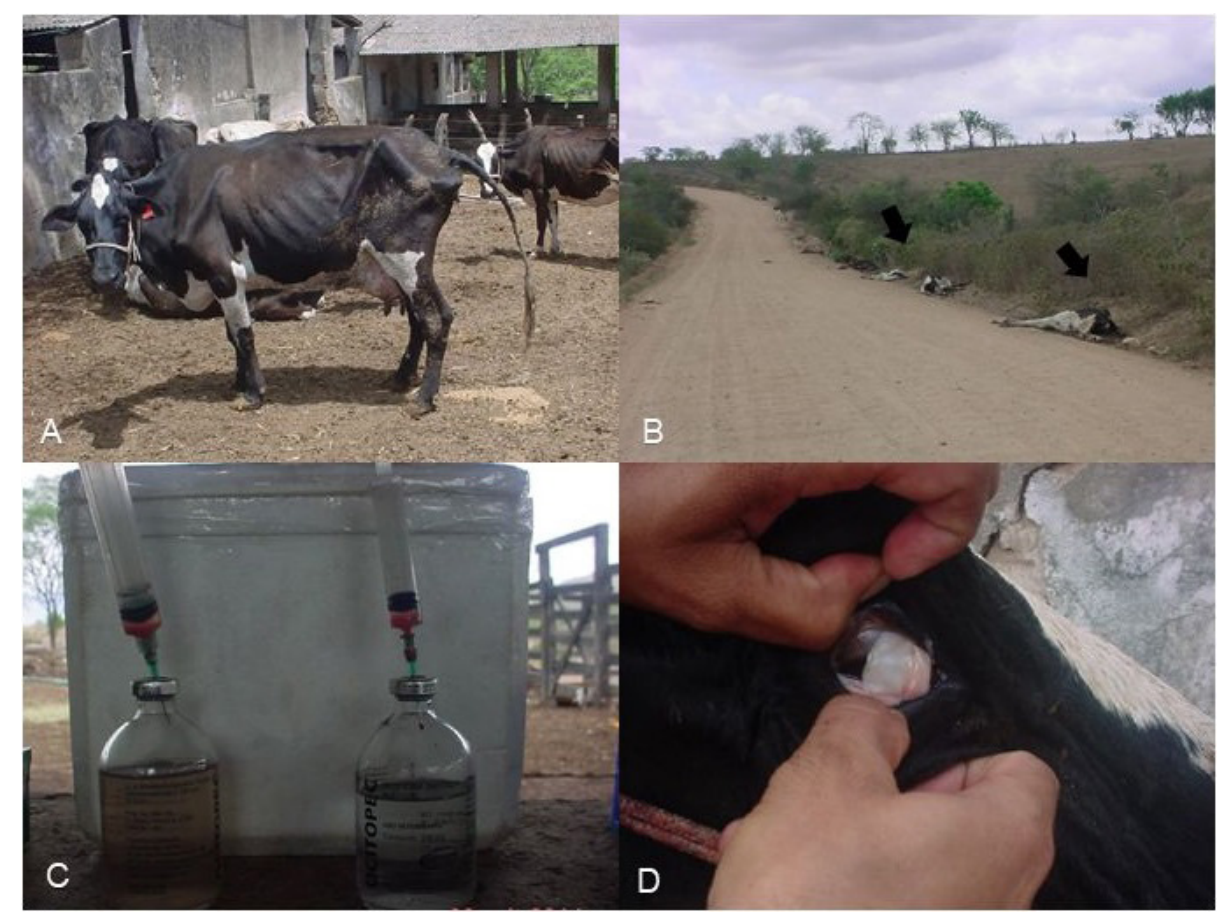

Figure 1. Animals affected by Trypanosoma vivax. (A) Animal presented weight loss and diarrhea. (B) High mortality of animals (arrows). (C) Use of oxytocin with sharing of needle and syringe, contaminated by blood. (D) Animal with pale ocular mucosa. 
presented, in addition to the signs found, nervous symptoms such as incoordination and aggression, and one animal had a abortion. Through the epidemiological inquiry, from the owner's information and observations made on the property inspection, it was found that about 30 days previously some animals had been introduced, purchased from the same region as the lactating herd. The climatic condition at the beginning of the outbreak was dry, and the animals were being semi-confined and fed corn silage and commercial concentrate. The cows were mechanically milked, however, oxytocin was used and the same needle and syringe shared between the animals under inadequate hygienic sanitary conditions. On the second and third visits to the property, held in December 2013 and in March 2014, respectively, it was evidenced that some animals maintained the previously reported body and clinical condition, but they remained aparasitemic. The animals that presented fever were being treated with diminazene diaceturate $(3.5 \mathrm{mg} / \mathrm{kg})$ in an uncontrolled manner. Some animals had been sold to neighboring farms, however, conditions of milking and oxytocin use with needle sharing were still maintained. On the fourth visit to the property in September 2014, it was found that the animals examined at the previous visit had died, and that the animals recently introduced into the lactating herd were becoming ill. In this interval, 10 animals died, and the inadequate sanitary hygienic conditions of milking, as well as the use of oxytocin sharing the same needle between the animals, were maintained.

\section{Property of the second outbreak}

Two diseased animals were hospitalized at the CBG and presented clinical signs of apathy, fever, grade II body score, anorexia, diarrhea, one was positive for Trypanosoma spp., in the blood smear, and one evolved to death. On the first visit to the farm, diseased animals were found that had the same signs as described above, including nervous symptoms (aggression, ataxia, and sialorrhea). Two animals abortion, and eight animals died of the disease. The climatic condition at the beginning of the outbreak was dry, with a low supply of food, and, thus, the animals were being fed with palm, commercial feed, and corn silage, in a semi-intensive regime. Although milking was mechanized, oxytocin was used with sharing of the same needle and syringe between the animals, without any hygienic discipline (Figure 1C). It was verified that seven days after the introduction of eight animals purchased from the State of Maranhão, dairy cows from the herd began to become ill. On the second visit to the farm, the was reported that some cows which became ill at the beginning of the outbreak had been sold and others did not gain weight and had diarrhea, but there had been no more deaths after the medication with diminazene diaceturate $(3.5 \mathrm{mg} / \mathrm{kg})$. It should be noted that one animal presented parasitemia, although it was asymptomatic. Changes in the management of milking were adopted, replacing part of the oxytocin used with the adoption of standing calves. However, the use of oxytocin with better hygienic practices was maintained in crossbred cows.

In the property of the third outbreak, 11 animals were diagnosed as affected by the disease, whose main signs were decreased milk production, apathy, anorexia, sialorrhea, pale mucosa, lymphadenomegaly, weight loss (Figure 1D), and of these five animals showed nervous signs such as aggression and incoordination. These were being treated by the owner with diminazene diaceturate $(3.5 \mathrm{mg} / \mathrm{kg})$, Oxytetracycline $(20 \mathrm{mg} / \mathrm{kg})$, calcium, and iron, with unsatisfactory results. Through the epidemiological inquiry, from information provided by the responsible veterinarian and caretakers, associated with the observations made at the property inspection, only lactating animals were found to be diseased, these were mechanically milked, and oxytocin was used at the moment of milking with sharing of needle and syringe.

\section{Detection of the parasite through parasitological diagnosis and hematological analysis}

\section{Property of the first outbreak}

Of the 24 blood samples collected from clinically ill animals, 29.17\% (07/24) presented trypomastigote forms of Trypanosoma spp. in stained blood smears and high parasitemia. Eight months later, 19 animals were tested again with negative results. 


\section{Property of the second outbreak}

Of the two animals hospitalized in the CBG, one presented trypomastigote forms of Trypanosoma spp. in stained blood smears, with high parasitemia. Eight months after the start of the outbreak, 11 animals were evaluated and one animal still presented trypomastigote forms of Trypanosoma spp. in the blood smear, however without clinical signs.

\section{Property of the third outbreak}

Of the 11 animals evaluated clinically, 18.18\% (2/11) presented trypomastigote forms of Trypanosoma spp. in stained blood smears (Figure 2).

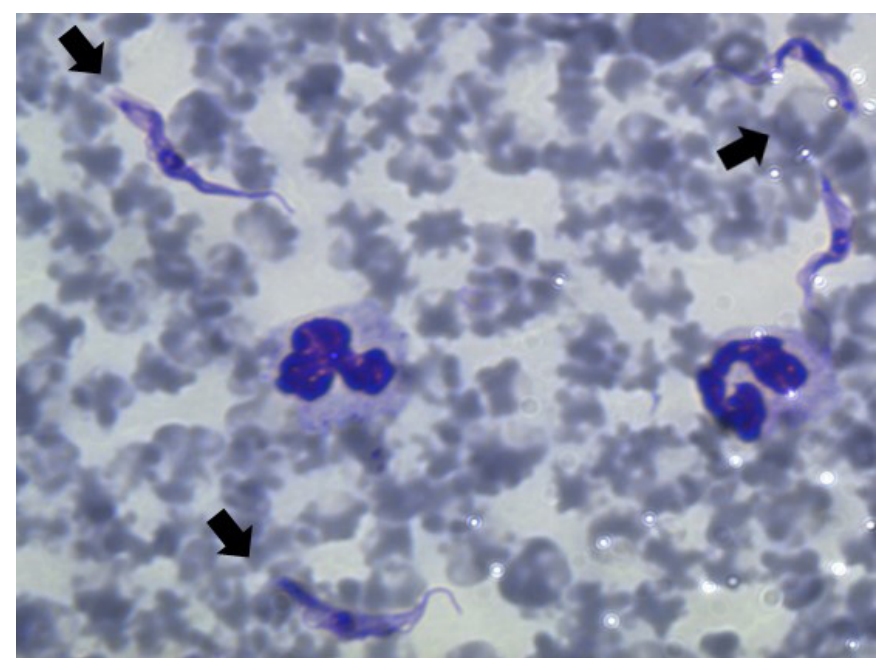

Figure 2. Trypanosoma vivax, viewed on a blood smear (Arrows).

In all the studied properties, the occurrence of Anaplasma marginale was observed in the blood smear in low parasitemia. Of the total samples analyzed, 13.76\% (15/109) presented infection with $A$. marginale. In the evaluation of the 72 samples corresponding to the three properties, it was verified that the hematocrit of the lactating animals had an average value of $22 \%$ (10\% to $37 \%)$, the plasma protein an average value of $7.55 \mathrm{~g} / \mathrm{dl}$ (5.4g/dl to $10.0 \mathrm{~g} / \mathrm{dl})$, and $22.23 \%$ (16/72) presented hypoproteinemia. Regarding plasma fibrinogen, the mean value obtained was $700 \mathrm{mgdl}$ (200mg/dl to $1600 \mathrm{mg} / \mathrm{dl}$ ), and 50\% (36/72) presented hyperfibrinogenemia. Regarding the hemogram result of the 13 clinically ill animals, 69.23\% (9/13) presented normocytic normochromic anemia, and 53.84\% (7/13) presented leukocytosis, in 46.15\% (6/13) through neutrophilia and regenerative left shift (Table 1).

\section{Parasitological, serological, and molecular diagnosis}

Of the 109 blood samples tested, 94\% (103/109) were seropositive in the ELISA for Trypanosoma vivax, 92\% (100/109) were seropositive in the RIFI for this agent, 15\% (17/109) were positive in conventional PCR, and 9\% (10/109) presented Trypanosoma vivax trypomastigote forms in the blood smear (Figure 3). In the $2 \%$ agarose gel electrophoresis stained with ethidium bromide, amplicons with 177 base pairs were observed (Figure 4).

Sequencing and sequence analysis Sequencing of the two samples analyzed in this study demonstrated 100\% identity with Trypanosoma vivax samples (GenBank accession no. EU753801.1).

\section{Discussion}

In Brazil, Trypanosoma vivax has been diagnosed in cattle in several states, with a high mortality of parasitized animals (Bastos et al., 2017; Batista et al., 2007; Cadioli et al., 2012; Carvalho et al., 2008; Guerra et al., 2008; Linhares et al., 2006; Madruga et al., 2006; Silva et al., 1996; Silva et al., 


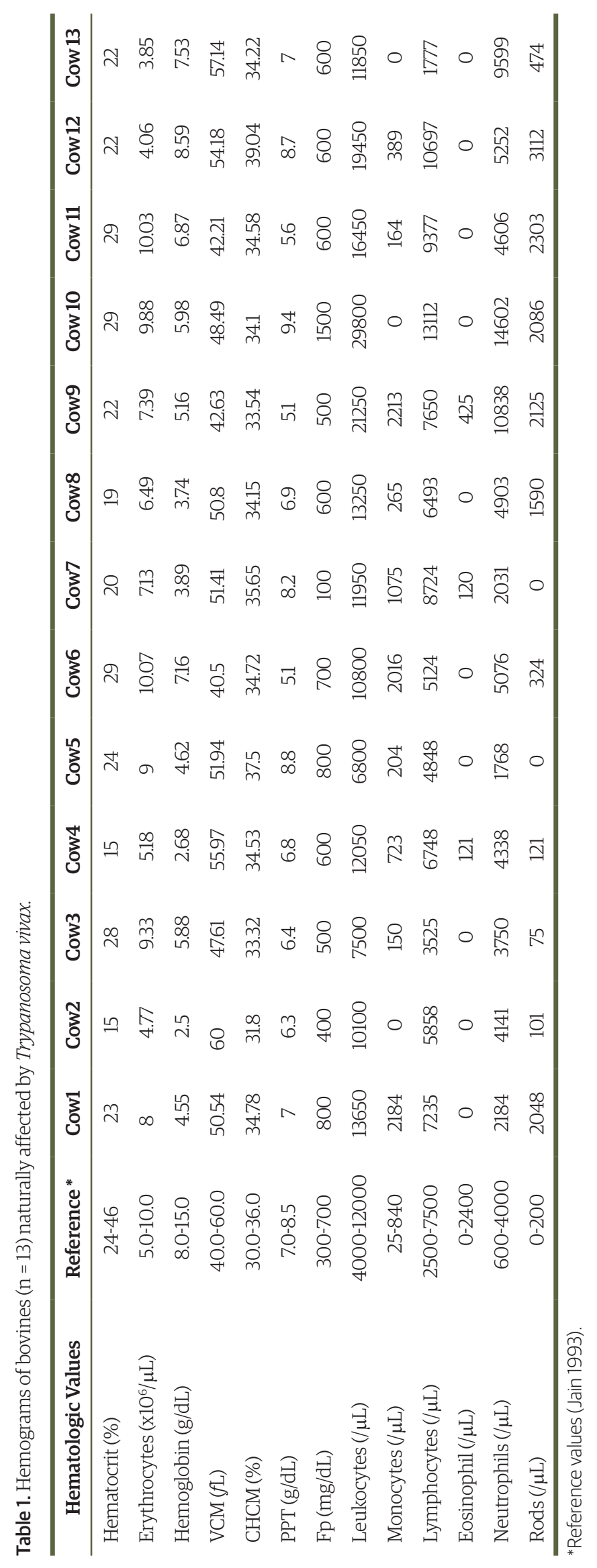




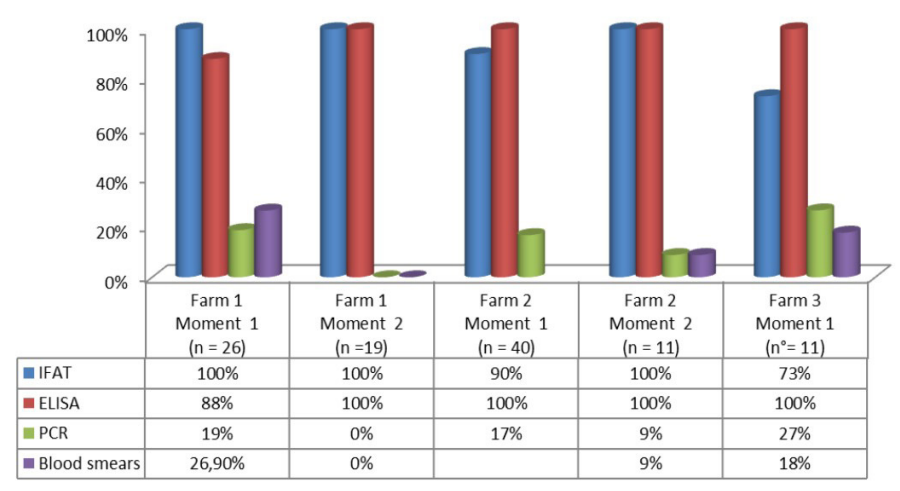

Figure 3. Parasitological, serological, and molecular diagnosis of trypanosomiasis in three dairy farms. Farm 1-Municipality of BomConselho/PE. Farm 2 - Municipality of Pedra/PE. Farm 3- Municipality of Arapiraca/AL.

$\begin{array}{llllllllllllllllll}1 & 2 & 3 & 4 & 5 & 6 & 7 & 8 & 9 & 10 & 11 & 12 & 13 & 14 & 15 & 16 & 17 & 18\end{array}$

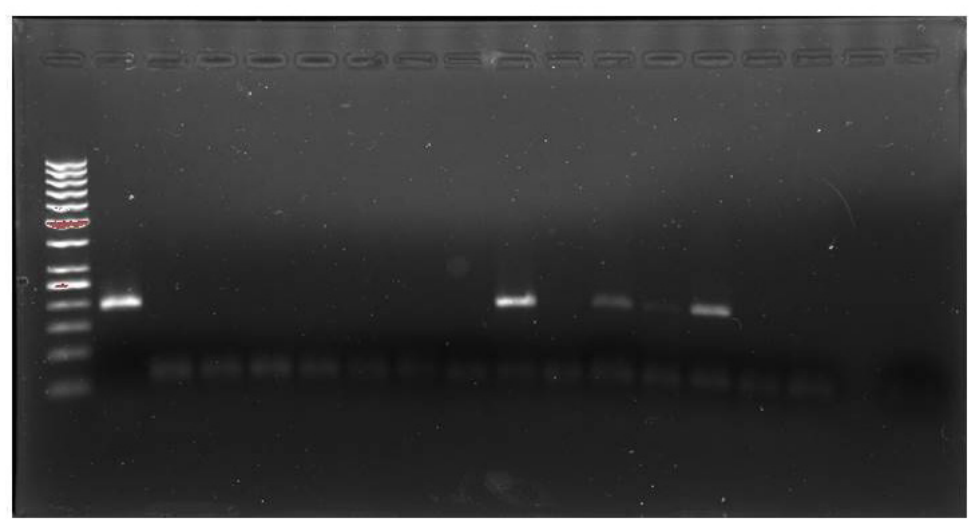

Figure 4. 2\% agarose gel electrophoresis. The amplimers shown in the photo correspond to; (1) 50 bp molecular scale marker (Invitrogen ${ }^{\circledR}$ ); (2) positive control; (3) Negative control; (4-9,11,15-18) negative samples; (10,12-14) positive samples for Trypanosoma vivax.

2009). In the State of Alagoas the presence of trypanosomiasis in herds had not previously been documented. In the farm in the municipality of Arapiraca/AL where the outbreak occurred, four months ago, animal deaths occurred on the property. These animals presented decreased milk production, apathy, anorexia, weight loss, fever, sialorrhea, and pale mucous membranes. In addition, one animal presented nervous symptoms, two animals abortion, and, in total, 15 animals died. The clinical and epidemiological characteristics of the animals involved showed that the first cases occurred after the purchase of animals from other states and introduced into the herd, the same was observed in outbreaks described in the states of São Paulo, Sergipe, and Goiás (Bastos et al., 2017; Cadioli et al., 2012; Vieira et al., 2017). In order to genetically improve their herds, several properties acquire animals from different regions of the country (Batista et al., 2008). This suggests that the transit of cattle allowed the entry of Trypanosoma vivax onto the farm. Additionally, this farm has a history of acquisition of animals from the states of Pernambuco and Maranhão. Another important factor is that on the farm studied here, oxytocin was intravenously administered to cows every day prior to milking, using the same needle and syringe for all animals.

Considering the increase in the endemic area of Trypanosoma vivax in Brazil, provoking important economic losses for bovine animals, epidemiological and etiological diagnoses become essential (Madruga et al., 2006). According to Pimentel et al. (2012) it is probable that the introduction of this parasite in Pernambuco, previously considered a free area, also occurred due to the transit of chronically infected animals from regions of occurrence of the parasite. Data obtained by Guerra et al. (2013) allowed the characterization of the state of Pernambuco as an area of enzootic instability for Trypanosoma vivax. This enzootic instability probably occurs as a 
consequence of the unfavorable environment for the development of vectors such as tabanidae (Paiva et al., 2000), Haematobia irritans and Stomoxys calcitrans (Cadioli et al., 2012) during most of the year because of the prolonged periods of droughts and high temperatures (Batista et al., 2008). From the results of this study it is known that trypanosomiasis exists in the dairy cattle herds of the states of Pernambuco and Alagoas, which is of great epidemiological importance for regions free of the parasite, since free trade in cattle is frequent in these regions.

The most commonly observed clinical findings in this study, such as apathy, anorexia, weight loss, diarrhea, lymphadenomegaly, pale mucous membranes, and fever are in agreement with those observed in the literature in clinical cases of trypanosomiasis by Trypanosoma vivax (Carvalho et al., 2008; Cadioli et al., 2012). Nervous symptomatology and abortion have also been described previously (Batista et al., 2007; Cuglovici et al., 2010).

The clinical conditions, with some seriousness, presented by the animals as a result of the natural infection by Trypanosoma vivax are justified by the fact that susceptibility of the animals to this pathogen is associated with several factors such as: age, nutritional stress or poor diet, competition for food, climatic factors, intercurrent infections, pregnancy, and lactation, with emphasis on the importance of nutrition as a major factor (Madruga, 2004). The influence of the dry season and food shortages during the outbreak period was associated with the lactation condition of the affected animals, which favored a low immune response to Trypanosoma vivax infection, contributing to the intensity of the clinical signs. In addition, the entry of animals from other endemic regions without the use of quarantine caused the occurrence of outbreaks of trypanosomiasis in the evaluated properties. However, the striking fact that contributed decisively to the spread of the disease was the indiscriminate use of oxytocin with constant needle sharing in all milking, associated with the poor sanitary conditions. This condition of iatrogenic transmission through the shared use of needles was reported by Cadioli et al. (2012) as an important risk factor for the occurrence of the disease in the state of São Paulo.

In the literature, several authors have associated the Trypanosoma vivax infection with the rainy season and the increase in the tabanid vectors at that time (Batista et al., 2007; Batista et al., 2009, Cuglovici et al., 2010). However, in the regions of the outbreaks described in the present study, pluviometric indices were well below the averages observed. In contrast, the positive correlation between the presence of Stomoxys calcitrans and temperatures above $20^{\circ} \mathrm{C}$ observed by Rodríguez-Batista et al. (2005) corroborates the average temperatures observed in the regions where the outbreaks occurred. However, in the visits to the properties, no Stomoxys calcitrans, Haematobia irritans, or tabanidae were found, arthropods incriminated as vectors of Trypanosoma vivax. Together with these observations, the disease was only affecting the lactating cows in the three evaluated properties, which makes the participation of the iatrogenic form, shared use of the oxytocin needle, the main route of transmission of the disease in the herds under study.

Another factor to be considered was the trade in animals diagnosed with the disease and treated with diminazene diaceturate indiscriminately by the owners, without adopting other adequate sanitary measures. This fact makes this disease difficult to control, since the possibility of drug resistance and development of asymptomatic carriers are responsible for the maintenance of the parasite in the herd, considering that fluctuations in parasitemia or even aparasitemic intervals can occur and are related to the immune response of the host (Almeida et al., 2010).

Anemia was the main finding in the hemogram of sick animals, as observed by other authors (Batista et al., 2007; Cadioli et al., 2012; Fidelis Junior et al., 2016). In infections caused by Trypanosoma vivax anemia is attributed to factors related to both parasite and host. However, immune-mediated mechanisms through deposition of immune complexes on the surface of red blood cells, the production of trans-sialidases and neuraminidases by Trypanosoma vivax that cleave sialic acid from the surface of red blood cells, resulting in an increase in phagocytosis and extravascular hemolysis, are the main factors responsible for hemolytic anemia (Connor \& Van Den Boosche, 2004; Guegan et al., 2013).

Regarding the results of the hematocrit in the present study, it was verified that the hematocrit of the lactation animals had an average value of $22 \%$ (10\% to 37\%). Batista et al. (2008), in the state of Paraiba, evaluated the hemogram of 36 animals, and 17 presented hematocrit ranging from 15-22\%. Linhares et al. (2006) observed hematocrit ranging from 15-20\% in animals containing trypomastigotes in blood smears. Cuglovici et al. (2010) observed a hematocrit variation of 
11 to $38 \%$, with a large proportion of positive animals presenting values below $24 \%$. However, these findings contradict those reported by Moura et al. (2009), who did not find alterations in the hematological values in bovines naturally infected by Trypanosoma vivax.

The findings for the plasma protein in this study are inconsistent with those reported by Sekoni et al. (1990), who observed a slight decrease in the total plasma protein values of bulls experimentally infected with Trypanosoma vivax, obtaining minimum values in the second post-infection week. A decrease in total serum proteins was also reported by Schenk et al. (2001), in experimental infection of calves, especially in the first days post-infection, and an increase in globulins after the second week post infection, probably attributed to the antigenic stimulation triggered by the parasite itself. Corroborating with these findings, Silva et al. (2009) and Fidelis Junior et al. (2016), also found decreased values of albumin and elevated globulin in bovines naturally infected with Trypanosoma vivax.

Regarding plasma fibrinogen, 50\% of the animals presented hyperfibrinogenemia, corroborating the results obtained by Cadioli et al. (2012) in naturally infected animals. However, in experimental infection in cattle, Paiva et al. (2000) did not find alterations in mean fibrinogen levels up to the 42nd post-infection day, although, after this, a reduction occurred, possibly related to the fact that the agent is capable of promoting intravascular coagulation.

In relation to the evaluation of the leukogram of the clinically diseased animals, we observed leukocytosis with lymphocytosis by neutrophilia and regenerative left shift, corroborating the results of Moura et al. (2009), who also found lymphocytosis and eosinophilia. However, Cadioli et al. (2012) initially reported leukopenia and subsequently leukocytosis. These inconsistent leukocyte responses in Trypanosoma vivax infections probably depend on the period of infection and can present normal, increased, or decreased values (Herrera et al. 2004).

Although the blood smear is a technique with low sensitivity, in this study it was shown to be an important diagnostic tool when performed in the parasitic phase, in order to monitor the parasitemia of the herd. However, according to Madruga et al. (2006) fluctuations of parasitemia occur during the infection by Trypanosoma vivax, making it difficult to find trypomastigote forms in blood smears. On the other hand, even in the diseased animals in the properties where the outbreaks occurred, which were previously medicated with diminazene diaceturate, it was possible to diagnose positive animals at the beginning of the outbreak, and after eight months, with this technique. According to Cadioli et al. (2012) there is the possibility of resistance of the parasite to the drug diminazene diaceturate when it is used in low doses $(3.5 \mathrm{mg} / \mathrm{kg})$ and continuously which allows the return of the parasitemia and the permanence of animals with Trypanosoma vivax in the herd.

Due to the low sensitivity of traditional parasitological methods and the difficulty of diagnosis in animals with low parasitemia (Rebenski et al., 1999), the detection of anti-Trypanosoma antibodies, as observed in the animals under study, provided accurate information on the situation of trypanosomiasis in the herds. In addition, the persistence of the antibodies was verified for several months, even after the curative treatment of the animals (Mattioli et al., 2001; Delafosse et al., 2006).

In the present study, the ELISA was able to detect more positive samples in relation to IFAT, corroborating the results obtained by Sampaio et al. (2015). However, according to Madruga et al. (2006) and Cuglovici et al. (2010) both serological tests have high sensitivity and specificity, with low percentages of cross-reaction in relation to Trypanosoma evansi, as well as which, in both tests, there is no cross-reaction with animals co-infected with Babesia bovis and Anaplasma marginale. Therefore, their use is recommended in epidemiological studies, even in animals co-infected with other hemoparasites (Platt \& Adams, 1976; Madruga et al., 2006).

The PCR presented a higher detection rate of positive samples when compared to the blood smear in the present study. However, during the acute phase of infection, molecular methods have the same sensitivity as parasitological methods (Desquesnes \& Dávila, 2002). Cuglovici et al. (2010), comparing the PCR to the parasitic test of Woo (1970), observed a higher sensitivity of PCR, although positive animals in the Woo test and negative in the PCR were also observed. In view of this, it can be seen that PCR can present a false negative result, a conclusion also described by Gonzales et al. (2003) and Gonzales et al. (2007). Desquesnes \& Dávila (2002) stated that a blood concentration of trypanosomes below one parasite per liter of blood (0.000001 trypanosome/ $\mu \mathrm{l} \mathrm{blood)} \mathrm{is} \mathrm{responsible} \mathrm{for} \mathrm{the} \mathrm{false} \mathrm{negative} \mathrm{results} \mathrm{of} \mathrm{PCR.}$ 
Consequently, there are still factors of inhibition of PCR that may be present in the samples, such as hemoglobin, heparin, or even DNAases, causing destruction of the DNA and the specific sequence investigated (Guclovici et al., 2010). In turn, Cadioli et al. (2015), demonstrate that in animals in parasitic periods, another molecular diagnostic technique, LAMP, presents greater sensitivity in the detection of animals with Trypanosoma vivax compared to conventional PCR.

Sequencing of the samples from the present study demonstrated 100\% identity for Trypanosoma vivaxand identified this agent as being responsible for the outbreaks. The Brazilian populations of Trypanosoma vivax are genetically homogeneous, although they may trigger different clinical findings, which characterizes that similar Trypanosoma vivax isolates may vary in pathogenicity and lethality (Cortez et al. 2006).

\section{Conclusion}

The conditions that triggered the disease in the three properties in this study had common points, which represented a high risk, namely: entry of animals purchased from other localities before the outbreaks, restriction of the disease to the lactation herd, and, mainly, sharing of needles and syringes contaminated with Trypanosoma vivax among the animals. From the results of this study it is known that trypanosomiasis exists in the dairy cattle herd of the states of Pernambuco and Alagoas, which is of great epidemiological importance for regions free of the parasite, since free trade in cattle is frequent in these regions.

The serological tests were efficient to evaluate the epidemiological situation of the herd. However, PCR revealed a low detection rate compared to serological tests since the animals were already being treated with trypanocid drugs.

In these situations of very low parasitemias, more sensitive molecular techniques, such as LAMP, should be employed. Trypanosomiasis is a disease that must be considered in cattle breeding in the regions studied as the cause of outbreaks and leading to high economic losses to the herd, triggering high animal mortality and expressive losses in milk production due to inadequate management of the herd. Hygienic and safety measures should be adopted during the administration of oxytocin in lactating cows. This practice, when performed with shared needles and without disinfection, is the main risk factor for the transmission of trypanosomiasis in dairy herds in regions where the disease is prevalent, increasing the challenge of reinfection among animals.

\section{Acknowledgements}

The Bovine Clinic, Garanhuns, UFRPE/CBG. The of professionals and students of the Department of Veterinary Pathology, Immunoparasitology of the FCAV-UNESP, Jaboticabal, São Paulo. In particular, my thanks to Dr. Rosangela Zacarias Machado and Dr. Marcos Rogério André for the support in the diagnostic analyzes since study. CAPES for granting the master's degree grant and CAPES/PROCAD NF (National Program for Academic Cooperation) for research assistance (Case no. 2009 362-10).

\section{References}

Almeida, K. S., Freitas, F. L. C., Tebaldi, J. H., Alessi, A. C., Machado, R. Z., \& Nascimento, A. A. (2010). Alterações clínicas, histopatológicas e enzimáticas em ovinos infectados experimentalmente por Trypanosoma vivax. Ciência Animal Brasileira, 11(3), 669-676. http://dx.doi.org/10.5216/cab.v11i3.5971.

Aquino, L. P., Machado, R. Z., Alessi, A. C., Marques, L. C., Castro, M. B., \& Malheiros, E. B. (1999). Clinical, parasitological and immunological aspects of experimental infection with Trypanosoma evansiin dogs. Memorias do Instituto Oswaldo Cruz, 94(2), 255-260. http://dx.doi.org/10.1590/s0074-02761999000200025. PMid:10224539.

Bastos, T. S. A., Faria, A. M., Madrid, D. M. C., Bessa, L. C., Linhares, G. F. C., Fidelis Junior, O. L., Sampaio, P. H., Cruz, B. C., Cruvinel, L. B., Nicaretta, J. E., Machado, R. Z., Costa, A. J., \& Lopes, W. D. Z. (2017). First outbreak and subsequent cases of Trypanosoma vivax in the state of Goiás, Brazil. Revista Brasileira de Parasitologia Veterinária, 26(3), 366-371. http://dx.doi.org/10.1590/s1984-29612017019. PMid:28678894.

Batista, J. S., Bezerra, F. S. B., Lira, R. A., Carvalho, J. R. G., Rosado Neto, A. M., Petri, A. A., \& Teixeira, M. M. G. (2008). Aspectos clínicos, epidemiológicos e patológicos da infecção natural em bovinos por Trypanosoma vivaxna Paraíba. Pesquisa Veterinária Brasileira, 28(1), 63-69. http://dx.doi.org/10.1590/s0100-736X2008000100010. 
Batista, J. S., Oliveira, A. F., Rodrigues, C. M. F., Damasceno, C. A. R., Oliveira, I. R. S., Alves, H. M., Paiva, E. S., Brito, P. D., Medeiros, J. M. F., Rodrigues, A. C., \& Teixeira, M. M. G. (2009). Infection by trypanossoma vivaxin goats and sheep in the Brazilian semiarid region: From acute disease outbreak to chronic cryptic infection. Veterinary Parasitology, 165(1-2), 131-135. http://dx.doi.org/10.1016/j.vetpar.2009.07.005. PMid:19665308.

Batista, J. S., Riet-Correa, F., Teixeira, M. M., Madruga, C. R., Simões, S. D., \& Maia, T. F. (2007). Trypanosomiasis by Trypanosoma vivax in cattle in the Brazilian semiarid. Description of an outbreak and lesions in the nervous system. Veterinary Parasitology, 143(2), 174-181. http://dx.doi.org/10.1016/j.vetpar.2006.08.017. PMid:16965857.

Batista, J. S., Rodrigues, C. M., Olinda, R. G., Silva, T. M., Vale, R. G., Câmara, A. C., Rebouças, R. E., Bezerra, F. S., Garcia, H. A., \& Teixeira, M. M. (2012). Highly debilitating natural Trypanosoma vivax infections in Brazilian calves: epidemiology, pathology, and probable transplacental transmission. Veterinary Parasitology, 110(1), 73-80. http://dx.doi.org/10.1007/s00436-011-2452-y. PMid:21626156.

Boulhosa J. (1946). Informação Científica (Boletim Técnico, pp. 21-26). Rio de Janeiro: Ministério da Agricultura.

Cadioli, F. A., Barnabé, Pde. A., Machado, R. Z., Teixeira, M. C., André, M. R., Sampaio, P. H., Fidélis Junior, O. L., Teixeira, M. M., \& Marques, L. C. (2012). First report of Trypanosoma vivax outbreak in dairy cattle in São Paulo State, Brazil. Revista Brasileira de Parasitologia Veterinária, 21(2), 118-124. http://dx.doi.org/10.1590/ S1984-29612012000200009. PMid:22832751.

Cadioli, F. A., Fidelis Junior, O. L., Sampaio, P. H., Santos, G. N., André, M. R., Castilho, K. J., \& Machado, R. Z. (2014). Detection of Trypanosoma vivax using PCR and LAMP during aparasitemic periods. Veterinary Parasitology, 174-177, 2015. PMid:26414906.

Carvalho, A. U., Abrão, D. C., Facury Filho, E. J., Paes, P. R. O., \& Ribeiro, M. F. B. (2008). Ocorrência de Trypanosoma vivax no estado de Minas Gerais. Arquivo Brasileiro de Medicina Veterinária e Zootecnia, 60(3), 769-771. http:/l dx.doi.org/10.1590/S0102-09352008000300037.

Connor, R. J., \& Van Den Boosche, P. (2004). African animal trypanosomoses. In J.A.W. Coetzer \& R.C. Tustin (Eds.), Infectious diseases of livestock. (2nd ed., pp. 251-296). South Africa: Oxford University Press.

Cortez, A. P., Rodrigues, A. C., Garcia, H. A., Neves, L., Batista, J. S., Bengaly, Z., Paiva, F., \& Teixeira, M. M. (2009). Cathepsin L-like genes of Trypanosoma vivax from Africa and South America--characterization, relationships and diagnostic implications. Molecular and Cellular Probes, 23(1), 44-51. http://dx.doi.org/10.1016/j.mcp.2008.11.003. PMid:19063960.

Cortez, A. P., Ventura, R. M., Rodrigues, A. C., Batista, J. S., Paiva, F., Añez, N., Machado, R. Z., Gibson, W. C., \& Teixeira, M. M. (2006). The taxonomic and phylogenetic relationships of Trypanossoma vivax from South América and África. Veterinary Parasitology, 133(Pt 2), 159-169. http://dx.doi.org/10.1017/S0031182006000254. PMid:16650339.

Cuglovici, D. A., Bartholomeu, D. C., Reis-Cunha, J. L., Carvalho, A. U., \& Ribeiro, M. F. (2010). Epidemiologic aspectos of na outbreak of Trypanosoma vivax in a dairy cattle herd in Minas Gerais state, Brazil. Veterinary Parasitology, 169(3-4), 320-326. http://dx.doi.org/10.1016/j.vetpar.2009.12.041. PMid:20138431.

Delafosse, A., Thébaud, E., Desquesnes, M., \& Michaux, Y. (2006). Epidemiology of Trypanosoma vivaxinfection in cattle in the tse-tse free area of Lake Chad. Preventive Veterinary Medicine, 74(2-3), 108-119. http://dx.doi. org/10.1016/j.prevetmed.2005.10.006. PMid:16321453.

Desquesnes, M., \& Dávila, A. M. R. (2002). Applications of PCR-based tools for detection and identification of animal trypanosomes: a review and perspectives. Veterinary Parasitology, 109(3-4), 213-231. http://dx.doi. org/10.1016/S0304-4017(02)00270-4. PMid:12423934.

Dirksen, G., Gründer, H-D. \& Stöber, M. (1993). Rosenberger: Exame clínico dos bovinos. (3. ed. 419 p). Guanabara Koogan: Rio de Janeiro.

Fidelis Junior, O. L., Sampaio, P. H., Machado, R. Z., André, M. R., Marques, L. C., \& Cadioli, F. A. (2016). C \& Cadioli F.A. Evaluation of clinical signs, parasitemia, hematologic and biochemical changes in cattle experimentally infected with Trypanosoma vivax. Revista Brasileira de Parasitologia Veterinária, 25(1), 69-81. http://dx.doi. org/10.1590/S1984-29612016013. PMid:27007249.

Gonzales, J. L., Chacon, E., Miranda, M., Loza, A., \& Siles, L. M. (2007). Bovine trypanosomosis in the Bolivian Pantanal. Veterinary Parasitology, 146(1-2), 9-16. http://dx.doi.org/10.1016/j.vetpar.2007.02.010. PMid:17374452.

Gonzales, J. L., Jones, T. W., Picozzi, K., \& Cuellar, H. R. (2003). Evaluation of a polymerase chain reaction assay for the diagnosis of bovine tripanosomiasis and epidemiological surveillance in Bolivia. Kinetoplastid Biology and Disease, 2(1), 1-14. http://dx.doi.org/10.1186/1475-9292-2-8. PMid:14613492.

González, L. E., García, J. A., Núñez, C., Perrone, T. M., González-Baradat, B., Gonzatti, M. I., \& Reyna-Bello, A (2005). Trypanosoma vivax: a novel method for puIIFRcation from experimentally infected sheep blood. Experimental Parasitology, 111(2), 126-129. http://dx.doi.org/10.1016/j.exppara.2005.05.008. PMid:16023641.

Guegan, F., Plazolles, N., Baltz, T., \& Coustou, V. (2013). Erythrophagocytosis of desialylated red blood cells is responsible for anaemia during Trypanosoma vivax infection. Cellular Microbiology, 15(8), 1285-1303. http:// dx.doi.org/10.1111/cmi.12123. PMid:23421946.

Guerra, N. R., Monteiro, M. F. M., Sandes, H. M. M., Cruz, N. L. N., Ramos, C. A. N., Santana, V. L. A., Souza, M. M. A., \& Alves, L. C. (2013). Detecção de anticorpos IgGanti-Trypanosoma vivaxem bovinos através do teste de Imunofluorescência indireta. Pesquisa Veterinária Brasileira, 33(12), 1423-1426. http://dx.doi.org/10.1590/ s0100-736X2013001200005. 
Guerra, R. M. S. N. C., Feitosa Júnior, A. B., Santos, H. P., Abreu-Silva, A. L., \& Santos, A. C. G. (2008). Biometry of Trypanosoma vivax found in a calf in the state of Maranhão, Brasil. Ciência Rural, 38(3), 833-835. http://dx.doi. org/10.1590/S0103-84782008000300041.

Herrera, H. M., Dávila, A. M. R., Norek, A., Abreu, U. G., Souza, S. S., D’andrea, P. S., \& Jansen, A. M. (2004), Enzootiology of Trypanosoma evansi in Pantanal, Brazil. Veterinary Parasitology, 125(3-4), 263-275. http:// dx.doi.org/10.1016/j.vetpar.2004.07.013. PMid:15482883.

Jain, N. C. (1993). Essentials of Veterinary Hematology. (1. ed., p. 417). Philadelphia: Lea \& Febiger.

Linhares, G. F. C., Dias Filho, F. D., Fernandes, P. R., \& Duarte, S. C. (2006). Tripanossomíase em bovinos no município de Formoso do Araguaia, Tocantins: relato de caso. Ciência Animal Brasileira, 7, 455-460.

Madruga, C. R., Araújo, F. R., Carvalcante-Goes, G., Martins, C., Pfeifer, I. B., Ribeiro, L. R., Kessler, R. H., Soares, C. O., Miguita, M., Melo, E. P. S., Almeida, R. F. C., \& Lima Junior, M. S. C. (2006). The developmenteof na enzymelinkedimmunosorbentassay for Trypanosoma vivaxantibodiesand its use in epidemiologicalsurveys. Memorias do Instituto Oswaldo Cruz,101(7), 801-807.http://dx.doi.org/10.1590/s0074-02762006000700016. PMid:17160291.

Madruga, C. R. (2004). Diagnóstico e epidemiologia do Trypanosoma (Duttonella) vivaxno Brasil. Revista Brasileira de Parasitologia Veterinária, 13, 46-47.

Mascarenhas, C. J., Beltrão, A. B., Souza Junior, L. C., Galvão, G. M. J., Pereira, N. S. T., \& Miranda, F. L. J. (2005). Projeto cadastro de fontes de abastecimento por água subterrânea. Diagnóstico dos municípios. Recife: Serviço Geológico do Brasil e Programa de Desenvolvimento Energético dos Estados e Municípios.

Mattioli, R. C., Faye, J. A., \& Jaitner, J. (2001). Estimation of trypanosomal status by the buffy coat technique and an antibody ELISA for assessment of the impact of trypanosomosis on health and productivity of N'Dama cattle in the Gambia. VeterinaryParasitoology., 95(1), 25-35. PMid:11163695.

Moura, D. M., Paneto, J. C., Bittar, E. R., \& Bittar, J. F. F. (2009). Perfil bioquímico de bovinos naturalmente infectados por Trypanosoma vivax. Ciência Animal Brasileira, 1, 642-647.

Oliveira, J. B., Hernandez-Gamboa, J., Jimenez-Alfaro, C., Zeledon, R., Blandon, M., \& Urbina, A. (2009). First report of Trypanosoma vivax infection in dairy cattle from Costa Rica. Veterinary Parasitology, 163(1-2), 136139. http://dx.doi.org/10.1016/j.vetpar.2009.03.051. PMid:19414224.

Paiva, F., Lemos, R. A. A., Nakasato, L., Mori, A. E., Brum, K. B., \& Bernado, K. C. (2000). Ocorrência de Trypanosoma vivax em bovinos do Estado do Mato Grosso do Sul, Brasil. Acompanhamento clínico, laboratorial e anatomopatológico de rebanhos infectados. Revista Brasileira de Parasitologia Veterinária, 9, 135-141.

Pimentel, A.D.S., Ramosa, C.A.N., Ramosa, R.A.N., Araújo, F.R., Borbac, M.L., Faustino, M.A.G. \& Alves, L.C. (2012). Firstreportand molecular characterization of Trypanosoma vivax in cattle from state of Pernambuco, Brasil. Veterinary Parasytology, 185, 286-289. http://dx.doi.org/10.1016/j.vetpar.2011.10.019

Platt, K. B., \& Adams, L. G. (1976). Evaluation of the indirect fluorescent antibody test for detecting Trypanosoma vivax in South American cattle. Research in Veterinary Science, 21(1), 53-58. http://dx.doi.org/10.1016/s00345288(18)33393-9. PMid:781765.

Quispe, A. P., Chávez, V. A., Casas, A. E., Trigueros, V. A., \& Suárez, A. F. (2003). Prevalencia de Trypanosoma vivaxen bovinos de laprovincia de Coronel Portillo, Ucayali. Revista de Investigaciones Veterinarias del Perú, 14, 161-165.

Rebenski, D. E., Winger, E. M., Rogovic, B., Robinson, M. M., Crowther, J. R., \& Dwinger, R. H. (1999). Improvedmethods for thediagnosisofAfricantrypanosomosis. Memorias do Instituto Oswaldo Cruz, 94, 249-253.

Rodrigues, A. C., Garcia, H. A., Ortiz, P. A., Cortez, A. P., Martinkovic, F., Paiva, F., Batista, J. S., Minervino, A. H., Campaner, M., Pral, E. M., Alfieri, S., \& Teixeira, M. M. (2010). Cysteine proteases of Trypanosoma (Megatrypanum) theileri : Cathepsin L-like gene sequences as targets for phylogenetic analysis, genotyping diagnosis. Parasitology International, 59(3), 318-325. http://dx.doi.org/10.1016/j.parint.2010.03.002. PMid:20230907.

Rodríguez-Batista, Z., Leite, R. C., Oliveira, P. R., Lopes, C. M., \& Borges, L. M. (2005). Populational dynamics of Stomoxyscalcitrans L. (Diptera: Muscidae) in threebiocenosis, Minas Gerais, Brazil. VeterinaryParasitolology., 130(3-4), 343-346. PMid:15908125.

Sampaio, P. H., Fidelis Junior, O. L., Marques, L. C., Machado, R. Z., Barnabé, PDE. A., André, M. R., Balbuena, T. S., \& Cadioli, F. A. (2015). Acute-phase protein behavior in dairy cattle herd naturally infected with Trypanosoma vivax. Veterinary Parasitology, 211(3-4), 141-145. http://dx.doi.org/10.1016/j.vetpar.2015.05.014. PMid:26012859.

Schenk, M. A. M., Mendonça, C. L., Madruga, C. R., Kohayagawa, A., \& Araújo, F. R. (2001). Avaliação clínicolaboratorial de bovinos nelore infectados experimentalmente com Trypanosoma vivax. Pesquisa Veterinária Brasileira, 21(4), 157-163. http://dx.doi.org/10.1590/50100-736X2001000400006.

Sekoni, V. O., Saror, D. I., Njoku, C. O., Kumi-Diaka, J., \& Opaluwa, G. I. (1990). Comparative hematological changes following Trypanosoma vivax andTrypanosoma congolense infection in Zebu bulls. Veterinary Parasitology, 35(1-2), 11-19. http://dx.doi.org/10.1016/0304-4017(90)90112-0. PMid:2343522.

Silva, A. S., Oliveira, B. C., Zanette, A. R., Soares, C. D. M., Coradini, G., Polens, C. H., \& Santurio, J. (2007). M \& Monteiro S.G. Ocorrência de Trypanosoma evansiem bovinos de uma propriedade leiteira no município de Videira, Santa Catarina. Acta Scientiae Veterinariae, 35, 373-376.

Shaw, J. J., \& Lainson, R. (1972). Trypanosoma vivax in Brasil. Annals of Tropical Medicine and Parasitology, 66(1), 25-32. http://dx.doi.org/10.1080/00034983.1972.11686794. PMid:5021570. 
Silva, A. S., Costa, M. M., Polenz, F. M., Polenz, H. C., Teixeira, G. M. M., Lopes, A. T. S., \& Monteiro, G. S. (2009). Primeiro registro de Trypanosoma vivaxem bovinos no Estado do Rio Grande do Sul, Brasil. Ciência Rural, 39, 2550-2554.

Silva, R. A., Silva, J. A., Schneider, R. C., Freitas, J., Mesquita, D., Mesquita, T., Ramirez, L., Rivera Dávila, A. M., \& Pereira, M. E. (1996). Outbreak of Trypanossomiasisdue toTrypanosoma vivax (Ziemann,1905) in bovinesofthe Pantanal, Brasil. Memorias do Instituto Oswaldo Cruz, 91(5), 561-562. http://dx.doi.org/10.1590/ S0074-02761996000500005. PMid:9137742.

Silva, R. A. M. S., Seidl, A., Ramirez, L., \& Dávila, R. M. A. (2002). Trypanosoma evansi e Trypanosoma vivax: biologia, diagnóstico e controle (p. 141) Corumbá: Embrapa Pantanal.

Suárez, C., García, F., Román, D., Coronado, A., Perrone, T., Reyna, A., \& Parra, N. (2009). Factores de riesgoasociados a latripanosomosis bovina en explotaciones ganaderas de Venezuela. Zootecnia Tropical, 27, 363-372.

Ventura, C., Paiva, F., Silva, R., Takeda, G. F., Buck, G. A., \& Teixeira, M. M. (2001). Trypanosoma vivax: characterization of the spliced-leader gene of a Brazilian stock and species-specific detection by PCR amplification of an intergenic spacer sequence. Experimental Parasitology, 99(1), 37-48. http://dx.doi.org/10.1006/expr.2001.4641. PMid:11708832.

Vieira, O. L. E., Macedo, L. O., Santos, M. A. B., Silva, J. A. B. A., Mendonça, C. L., Faustino, M. A. D. G., Ramos, C. A. D. N., Alves, L. C., Ramos, R. A. N., \& Carvalho, G. A. (2017). Detection and molecular characterization of Trypanosoma (Duttonella) vivax in dairy cattle in the state of Sergipe, northeastern Brazil. Revista Brasileira de Parasitologia Veterinária, 26(4), 516-520. http://dx.doi.org/10.1590/s1984-29612017048. PMid:29091120.

Woo, P. T. K. (1970). The haematocrit centrifuge technique for the diagnosis of African trypanosomiasis. Acta Tropical Veterinary., 27(4), 384-386. PMid:4396363. 